\title{
Results of the Research on the Topic of Ecologically Safe Technology of Planting Potatoes with a Help of Liquid Organic Fertilizers
}

\author{
Baybulatov T.S. \\ Doctor of technical sciences, professor, \\ M. M. Dzhambulatov Dagestan State \\ Agricultural University \\ Makhachkala, Russia \\ baitaslim@yandex.ru
}

Chabibov S.R.

Doctor of technical sciences, assistant professor,

M. M. Dzhambulatov Dagestan State

Agricultural University

Makhachkala, Russia

Islamov M.G.

$\mathrm{PhD}$ student,

M. M. Dzhambulatov Dagestan State

Agricultural University

Makhachkala, Russia

\begin{abstract}
Current paper examines the usage of liquid fertilizers in Russia and abroad, states the effectiveness of the usage of liquid organic fertilizers, which is in reducing the cost of production and reducing the environmental impact on the environment.

We examine a resource-saving technology of using fertilizers when planting potatoes, for two-level fertilization: mineral fertilizers for planting potatoes and subsoil liquid organic fertilizers for the roots. We also examine a combined machine for the implementation of the described technology.

Our results demonstrate field experimental studies of the combined machine and the effectiveness of the subsurface introduction of PAs technology when planting potatoes. This technology is aimed to improve the water-air circulation of the arable soil layer: the average soil moisture at the depth of the potato tubers till stems death, ranged from $80.5 \%$ to $69.3 \%$, being under control in the same periods the humidity was $75.7-57.1 \%$. In improving the aggregate composition of the soil: fractions of $0.001 \ldots 0.025 \mathrm{~m}$ prevailed by $2.1 \%$, and soil particles with a size of $0.025 \ldots 0.05 \mathrm{~m}$ by $7.7 \%$. They promoted early sprouts, early flowering, and the later stems death, ensuring a long period of tuberization, which affected the amount of accumulated crop on average, over three years, the yield of potatoes increased by 3.36 t/ ha.
\end{abstract}

Keywords - liquid organic fertilizers, ecologically safe technology, soil, fertilization, planting, potatoes, combined machine, efficiency.

\author{
Magaramov I.B. \\ Candidate of agricultural sciences, assistant professor, \\ M. M. Dzhambulatov Dagestan State \\ Agricultural University \\ Makhachkala, Russia
}

Ajdemirov O.M.

M. M. Dzhambulatov Dagestan State

Agricultural University

Makhachkala, Russia

Minatullaev S.M.

Lecturer,

M. M. Dzhambulatov Dagestan State

Agricultural University

Makhachkala, Russia

\section{INTRODUCTION}

Recently, the problem of organic fertilizers accumulation has become particularly acute in the near-farm territories, while many of those are very strong environment polluters. At the same time, they are an ideal raw material for the cheap fertilizers preparation, the use of which will improve soil fertility and increase crop yields.

The effective use of organic fertilizers is still in-soil liquid fertilization, which provides better nutrients preservation, expands zones and period of their use and, consequently, increases the efficiency, as well as protects the environment. In addition, the in-soil fertilization using liquid fertilizers allows creating the best conditions for providing plants with nutrients that are located in the active zone of their root system.

The share of liquid fertilizer use remains in Russia significantly lower than in developed foreign countries. In the US, almost a third of mineral fertilizers are used in liquid form, in Russia their share is about $10 \%$. Along with this, the efficiency of using fertilizers is low, depending on a number of reasons, among which are methods of using liquid fertilizers and technical means for their application [9].

Traditionally, a continuous superficial liquid fertilization is the most widely used method in Russian agriculture, which entails an irrational consumption of fertilizers, uneven 
distribution, exceeding the allowable level by a factor of 2-3, and environmental pollution.

The expediency and necessity of combining technological operations are scientifically justified, verified and confirmed by practice $[1,2,3]$.

Combining the subsoil liquid organic fertilization together with potatoes planting allows planting potato tubers into moist freshly cultivated soil and, as a result, ensures their high field germination. At the same time, there are better conditions for the initial growth and development of plants, which guarantee consistently high and stable yields $[4,8]$

For planting potatoes and in-soil application of subsoil liquid organic fertilizers, a combined machine should be used, the novelty and originality of which is confirmed by the Russian Federation Patent for model No. 150371, which ensures the liquid organic fertilization into the loose root layer of the soil, and mineral fertilizers in coulters. Such fertilization allows you to create a mixture of fertilizers and soil directly in the areas of root development, for higher digestibility by plants $[5,6]$. $[5$, $6]$.

The main technical task is the possibility of combining several technological operations, namely: loosening the soil; planting potatoes and subsurface basal liquid organic fertilization in accordance with agrotechnical and ecological requirements.

The task can be solved with a help of a soil-cultivating planting machine containing a tank, pipelines, a pump, a bunker, a scooping and sowing mechanisms, a coulter, closing discs, sprayers on the frame in front of the coulters for a greater depth h (Figure 1). Also, there are feeding cultivators installed, in which sprayers are located for the subsurface liquid organic fertilization. Tanks with fertilizers are installed on the tractor $[5,6]$.

The novelty and originality of the combined machine is that the tillage machine performs following technological operations in one go: loosening the soil; planting potatoes; subsurface basal application of liquid organic fertilizers in accordance with agrotechnical requirements and ecology preservation rules.

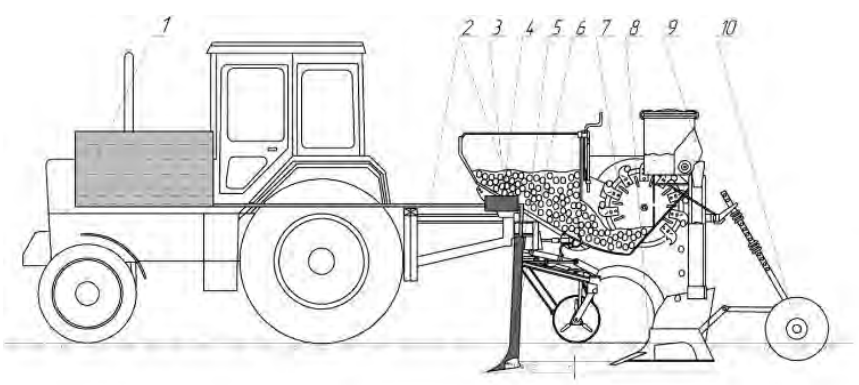

Fig. 1. The scheme of combined machine for the liquid organic fertilizers application when potatoes planting: 1- containers for fertilizers; 2 pipelines; 3 - bunker; 4 - pump; 5- feeding cultivator; 6 - sprayer; 7 scooping mechanism; 8 - coulter; 9 - sowing mechanism; 10 - closing disks

\section{METHODS AND MATERIALS}

To confirm the theoretical background, we carried out field experimental studies for 3 years (2015 ... 2017) in "Khubar", Kazbek district of the Republic of Dagestan.

In the experiments, pre-prepared liquid organic fertilizers (slurry) were used, at a dose of $15001 /$ ha. The area of 1 plot was: $100 \mathrm{mx} 2.8 \mathrm{~m}=280 \mathrm{~m} 2$, the length of the section corresponded to the size of the field, and the width was chosen according to the width of the capture of the $\mathrm{CH}-4 \mathrm{~B}$ potato planter. The size of the experimental plot - $240 \mathrm{~m} 2$.

Systematic options arrangement. Threefold repetition of an action.

Experiment scheme: mineral fertilizers + planting potatoes with potato planter SN-4B (control) and liquid organic fertilizers + mineral fertilizers + planting potatoes with potato planter SN-4B (experiment).

\section{RESULTS}

Potatoes need moistured soil at all stages of development, which is confirmed by many well-known scientists. The lack of moisture in soil during the period of tuberization leads to yield decrease, as the number of tubers under the bush and their size decreases.

Our research demonstrate that in-soil placement of liquid organic fertilizers when planting potatoes contributes to better soil moisture preservation compared to the control variant, and the presence of moisture in the soil will play a huge role in the morphological development period, in shaping the quantity and quality of the potato crop (table 1).

In-soil liquid organic fertilization when planting potatoes contributes to the improvement of the water-air circulation of the arable layer of the soil (0-0.2 m). In general, according to the experimental variant with in-soil liquid organic fertilization when planting potatoes, the average value of soil moisture, at the depth where potato tubers are formed, during the periods from the first shoots to the stems death, was in the range from $80.5 \%$ to $69.3 \%$. At the same time, it was $75.7-57.1 \%$, under the control over the same periods of humidity, which is significantly lower than the humidity of the proposed option.

TABLE I. INFLUENCE OF THE IN-SOIL APPLICATION OF LIQUID ORGANIC FERTILIZERS WHEN PLANTING POTATOES ON SOIL MOISTURE SUPPLY (IN \%)

\begin{tabular}{|c|c|c|c|c|}
\hline \multirow{2}{*}{$\begin{array}{c}\text { Experiment } \\
\text { options }\end{array}$} & \multirow{2}{*}{ Depth, m } & \multicolumn{3}{|c|}{$\begin{array}{c}\text { Potatoes development } \\
\text { phases }\end{array}$} \\
\cline { 3 - 5 } & $\begin{array}{c}\text { First } \\
\text { sprouts }\end{array}$ & $\begin{array}{c}\text { Early } \\
\text { bloom }\end{array}$ & $\begin{array}{c}\text { Stem } \\
\text { death }\end{array}$ \\
\hline \multirow{4}{*}{ Control } & $0-0.1$ & 74.2 & 38.4 & 54.4 \\
\cline { 2 - 5 } & $0.1-0.2$ & 77.3 & 43.6 & 59.8 \\
\cline { 2 - 5 } & $\begin{array}{c}\text { Average } \\
\text { value }\end{array}$ & 75.7 & 41.0 & 57.1 \\
\hline \multirow{3}{*}{ Experiment } & $0-0.1$ & 78.4 & 48.2 & 66.2 \\
\cline { 2 - 5 } & $0.1-0.2$ & 82.6 & 54.6 & 72.4 \\
\cline { 2 - 5 } & $\begin{array}{c}\text { Average } \\
\text { value }\end{array}$ & 80.5 & 51.4 & 69.3 \\
\hline
\end{tabular}


During all years of research, the in-soil liquid organic fertilization when planting potatoes contributed to the preservation of soil moisture both in the $0-0.1 \mathrm{~m}$ layer and in the 0.1-0.2 m layer, compared to the variant under control.

Field observations showed that when planting potatoes using the recommended technology, seedlings appeared earlier for 2-4 days, the onset and further phenological phases accelerated, stems death shifted to later periods, providing a long tuberization period, which affected the amount of harvest.

The use of a combined machine for the in-soil liquid organic fertilization when planting potatoes contributed to the improvement of the aggregate soil composition, which is explained by the combination of cultivation operations (with cultivators), in-soil liquid organic fertilization and planting potatoes. The cultivator cuts the weeds and loosens the soil, cuts the furrow with the coulters of the potato planter, cleans up closures with the closing discs, i.e. improves the aggregate composition of the soil.

Our experimental studies have shown that the aggregate soil composition is significantly affected by the speed of the combined machine. Therefore, the studies were carried out at different speeds of the combined machine for the in-soil liquid organic fertilization when planting potatoes $(v=1,66 ; 2,22 ; 2$, $77 \mathrm{~m} / \mathrm{sec}$ ).

The results of experimental studies and their analysis showed that with the technology of in-soil liquid organic fertilization together with potato planting, at the optimal speed of the combined machine $(v=2.22 \mathrm{~m} / \mathrm{s})$, the fraction content with particle sizes from 0.001 to $0.1 \mathrm{~m}$ is $62.4 \%$, which is $8.2 \%$ more than what is in the same fractions of the variant under control. The fractional composition of the soil $(0.001 \ldots 0.025$ and $0.025 \ldots 0.05 \mathrm{~m}$ ) improved by 2.1 and $7.7 \%$, respectively (Table 2).

TABLE II THE EFFECT OF THE COMBINED MACHINE SPEED ON THE AGGREGATE COMPOSITION OF THE SOIL, $\%$

\begin{tabular}{|c|c|c|c|c|c|}
\hline \multirow{2}{*}{ 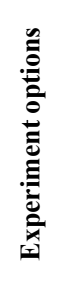 } & \multirow[b]{2}{*}{ 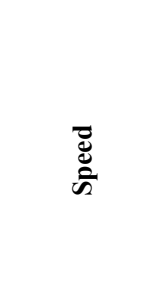 } & \multicolumn{4}{|c|}{ Fraction' sizes. m. } \\
\hline & & $\begin{array}{l}\bar{s} \\
\vdots \\
\vdots \\
\vdots \\
0\end{array}$ & 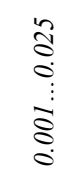 & 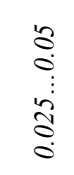 & $\begin{array}{l}7 \\
0 \\
\vdots \\
\vdots \\
8\end{array}$ \\
\hline \multirow{3}{*}{ 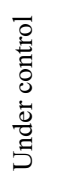 } & $v=1.66 \mathrm{~m} / \mathrm{s}$ & 51.9 & 12.2 & 21.1 & 14.8 \\
\hline & $\mathrm{v}=2.22 \mathrm{~m} / \mathrm{s}$ & 54.2 & 12.5 & 16.8 & 16.5 \\
\hline & $v=2.77 \mathrm{~m} / \mathrm{s}$ & 53.4 & 13.8 & 17.2 & 15.6 \\
\hline \multirow{3}{*}{ 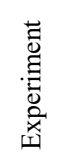 } & $v=1.66 \mathrm{~m} / \mathrm{s}$ & 60.8 & 14.2 & 15.6 & 9.4 \\
\hline & $v=2.22 \mathrm{~m} / \mathrm{s}$ & 62.4 & 14.6 & 14.2 & 8.8 \\
\hline & $v=2.77 \mathrm{~m} / \mathrm{s}$ & 62.2 & 15.8 & 11.4 & 10.4 \\
\hline
\end{tabular}

The data in the table shows that the use of the recommended technology and combined machines for in-soil liquid organic fertilization when planting potatoes at any speed improves the aggregate composition of the soil compared to the version of the experiment under control. It is explained by the additional dividing the soil into particles by the cultivators installed in front of the potato planters' mechanisms.

To ensure the high-quality spraying of liquid organic fertilizers, the installation height of the sprayer in the volumetric chamber of the cultivator plays an important role. Taking into account the space under the wings of a standard cultivator paw, we carried out the research using sprayers for applying liquid fertilizer FD 06 and $\mathrm{SJ}-7$ installed under the wings of the cultivator at the height of $h=0.02, h=0.04$ and $h$ $=0.06 \mathrm{~m}$ from the soil surface.

The results of experimental studies have shown that the required spray width $b=0.3 \mathrm{~m}$. is provided by both types of sprayers at any sprayer installation height; however, the most even spreading of liquid organic fertilizers is ensured when the sprayer is installed at the height $\mathrm{h}=0.04 \mathrm{~m}$ from the soil surface (Table 3).

TABLE III THE DISTRIBUTION OF THE WORKING FLUID ACROSS THE SPRAY WIDTH AT DIFFERENT INSTALLATION HEIGHTS OF THE SPRAYER

\begin{tabular}{|c|c|c|c|}
\hline \multirow{2}{*}{$№$} & $\begin{array}{c}\text { Sprayer' } \\
\text { installation height, } \\
\mathrm{m}\end{array}$ & \multicolumn{2}{|c|}{ Average value of spray width, $\mathrm{m}$} \\
\cline { 3 - 4 } & $\mathrm{h}$ & 0.27 & Sprayer FD 06 \\
\hline 1 & $\mathrm{~h}=0.02$ & 0.31 & 0.32 \\
\hline 2 & $\mathrm{~h}=0.04$ & 0.32 & 0.34 \\
\hline 3 & $\mathrm{~h}=0.06$ & 0.38 \\
\hline
\end{tabular}

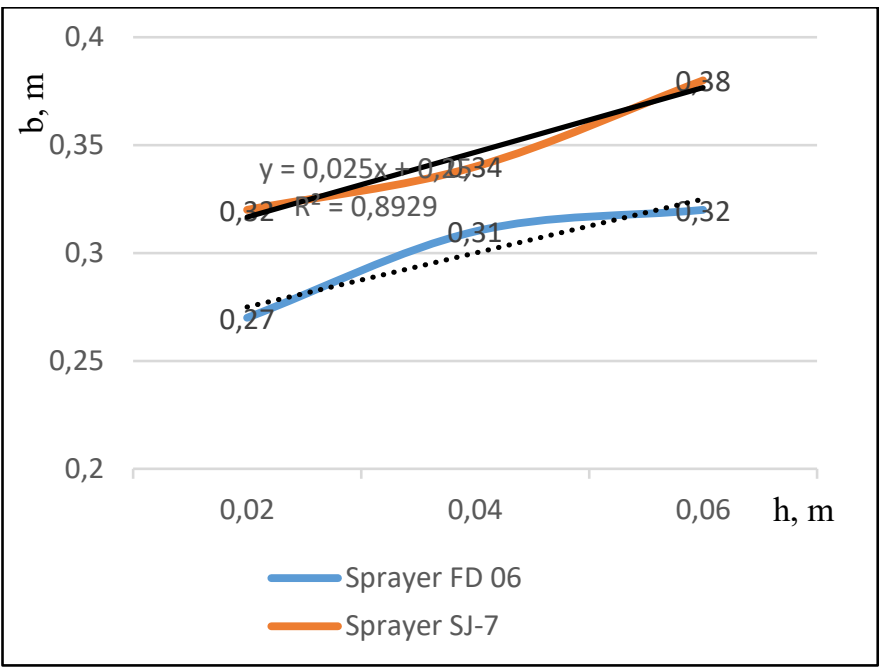

Fig. 2. The distribution of the working fluid across the spray width at different values of the sprayer installation height

The correlation-regression analyzes of experimental data allowed us to establish equations and theoretical regression lines for the fluid spreading across the spray width depending on the height of the sprayer installation in the wings of the cultivator paw (Figure 2).

The indicated dependence of the spray width on the installation height of the FD 06 sprayer is described by the following regression equation $\mathrm{Y}=0.025 \mathrm{x}+0.25$, and for the SJ-7 sprayer by the following equation: $\mathrm{Y}=0.03 \mathrm{x}+0.2867$. 
The correlation between the height of the sprayer installation and the spray width is reliable and strong $(\mathrm{R} 2=0.96$ and R2 $=0.89$ ), and the connection form is direct. The regression factor $\mathrm{rf}=0.025$ and $\mathrm{rf}=0.03$ is shown in which direction and at what amount on average, function (y) changes as the argument $(\mathrm{x})$ changes. The equations and regression lines show that an increase in the installation height of the sprayer by $0.01 \mathrm{~m}$ leads to an increase in the spray width of the working fluid by $0.025 \mathrm{~m}$ for FD 06 sprayers and by $0.03 \mathrm{~m}$ for SJ-7 sprayers.

Thus, the results of the laboratory experimental studies have shown that for in-soil application of liquid organic fertilizers with sprayers with installed volumetric chambers of cultivating paws it is advisable to use sprayers FD 06. These sprayers provide the required spray width and evenly spread the working fluid across the entire spray width. The optimal installation height of the sprayer is $\mathrm{h}=0.04 \mathrm{~m}$.

Field studies have shown that the use of a combined machine for in-soil application of liquid organic fertilizers when planting potatoes contributes to the preservation of soil moisture and an increase (by $4.8-12.2 \%$ ) of the average soil moisture when comparing to the variant under control at the depth of the potato tubers formation till the stems death.

The results of experimental studies have shown that at the optimum speed of the combined machine is $v=2.22 \mathrm{~m} / \mathrm{sec}$. At this speed the best aggregate soil composition is provided: fractions of soil with particle sizes from 0.001 to $0.1 \mathrm{~m}$ were $62.4 \%$, which is $8,2 \%$ more than the content of the same fractions in the variant under control, and the number of fractions of size $0.001 \ldots 0.025 \mathrm{~m}$ increased by $8.2 \%$, which is explained by the additional soil crumbling with the cultivator paws installed in front of the coulters of the potato planter. In addition, the results of experiments showed that the optimal sprayer installation height in the volumetric chamber of the cultivator paw is $0.04 \mathrm{~m}$.

Experimental studies have shown that in-soil application of liquid organic fertilizers when planting potatoes contributed to early sprouts and early flowering, the stems death shifted to later periods, providing a long period of tuberization, which affected the number and height of the bush (Table 4).

TABLE IV. INFLUENCE OF IN-SOIL LIQUID ORGANIC FERTILIZERS WHEN PLANTING POTATOES ON THE DEVELOPMENT OF POTATOES

\begin{tabular}{|c|c|c|c|}
\hline \multirow{2}{*}{$\begin{array}{c}\text { Experiment } \\
\text { options }\end{array}$} & Stems, units & Height, $m$ & $\begin{array}{c}\text { Stems weight, } \\
\text { grams per } \\
\text { bush }\end{array}$ \\
\cline { 2 - 4 } & 3.2 & 0.3 & 220 \\
\hline Under control & 3.8 & 0.38 & 234 \\
\hline Experiment & 3.8 &
\end{tabular}

Data analysis showed that when applying liquid organic fertilizers together with planting potatoes, it improves stem formation, increases the plant's stems, the total weight of the stems and the surface of the potato leaves.

Thus, in the experimental version with in-soil liquid organic fertilization when planting potatoes, compared with the version under control, the number of stems increased by 0.6 , the height of the plants increased by $0.08 \mathrm{~m}$, the total weight of the tops increased by 14 grams per bush.

In-soil local liquid organic fertilization when planting potatoes contributed to an early sprouts and early flowering, later stems death, ensuring a long tuber-formation period, which influenced the value of the crop.

The effect of in-soil application of liquid organic fertilizers is enhanced by their use together with mineral fertilizers. At the same time, the application amount is reduced by half, and yield gets higher (by $20-60 \%$ ) than in case of separate application of these fertilizers $[4,8,10]$.

The results of field studies have shown that the in-soil application of liquid organic fertilizers when planting potatoes contributed to an increase in the yield of potatoes in all the years of research (Table 5).

TABLE V. INFLUENCE OF THE IN-SOIL APPLICATION OF LIQUID ORGANIC FERTILIZERS DURING PLANTING ON POTATO YIELD

\begin{tabular}{|c|c|c|c|c|}
\hline \multirow{2}{*}{$\begin{array}{c}\text { Experiment } \\
\text { options }\end{array}$} & \multicolumn{3}{|c|}{ Potato yield, tons per hectare } & $\begin{array}{c}\text { Average value } \\
\text { for 3 years }\end{array}$ \\
\cline { 2 - 5 } & 2015 & 2016 & 2017 & 14.86 \\
\hline Under control & 14.22 & 16.56 & 13.8 & 18.22 \\
\hline Experiment & 18.64 & 19.70 & 16.32 & \\
\hline
\end{tabular}

According to our studies, by the years of observation, the yield of potatoes in 2015 and 2016, the yield in the experimental zone exceeded 2017 by $4.42 \ldots 3.14 \mathrm{t} / \mathrm{ha}$, respectively. At the same time, on average over three years, the yield of potatoes increased by $3.36 \mathrm{t} / \mathrm{ha}$.

\section{IV.CONCLUSION}

The results and the analysis of the experimental data proved that the recommended technology of in-soil application of liquid organic fertilizers together with planting, carried out by a combined machine, is resource saving, environmentally safe and economically viable.

\section{References}

[1] M.D. Abdulaev, M.G. Islamov, B.G. Magaramov, T.S. Baybulatov, "The technology of subsurface liquid organic fertilizer", Scientific Review, 2015, no. 24,. pp. 119-122.

[2] M.D. Abdulaev, R.K. Kamilov, T.S. Baybulatov, "The results of studies of the in-soil application of liquid organic fertilizers", Problems of development of the regional agro-industrial complex, 2016, vol. 1., no.. 1-2 (25), pp. 108-111.

[3] N.S. Avdonin, "Scientific basis for the use of fertilizers", Moscow: Kolos, 1998, pp. 69, 84-85, 145-147.

[4] E.D. Adinyaev, V.K. Kozanov, "How to increase the productivity of potatoes in North Ossetia", Potatoes and vegetables, 2008, no. 2, pp..5-6.

[5] T.S. Baybulatov, M.D. Abdulaev, M.G. Islamov, R.A. Gadzhiev, Tillage planting machine, Patent for a utility model RUS 150371. 07/04/2014.

[6] T.S. Baybulatov, M.D. Abdulaev, R.A. Gadzhiev, "Combined landing machine", In Collection: Academic science - problems and achievements, 2014, p. 135.

[7] M.G. Islamov, A.M. Ubaisov, M.G. Abdulnatypov, T.S. Baybulatov, "The justification of the technology of the in-soil application of liquid organic fertilizers and planting potatoes", Scientific journal "Chronos",2016, no. 1, pp. 17-20.

[8] M.G. Nugaev, T.S. Abdulnatipov, T.S. Baybulatov, "Justification of the factors affecting resource conservation in the application of liquid organic 
fertilizers", In Proc. of the International Scientific and Practical Conference, dedicated to the 85th anniversary of M. M. Dzhambulatov Dagestan State Agricultural University, Makhachkala, 2017. pp. 289-293 [Ways to improve the efficiency of agrarian science in terms of import substitution, 2017].
[9] N.F. Solovyov, "Liquid fertilizers and modern methods of their application", Scientific publication, Moscow: FGNU "Rosinformagrotekh", 2010.

[10] E.A. Sudzerovskaya et al., "Justification and Results of Research in the Technology of In-Soil Spreading of Liquid Organic Fertilizers", Problems of development of the regional agro-industrial complex, 2018, no. 1, pp. 123-126. 